\title{
Development of a Simple, Effective Ceramic Filter for Arsenic Removal
}

\author{
Md. SHAFIQUZZAMAN*, Md. Mahmudul HASAN*, Jun NAKAJIMA*, Iori MISHIMA** \\ *Department of Environmental Systems Engineering, Ritsumeikan University, 1-1-1 \\ Nojihigashi, Kusatsu, Shiga 525-8577, Japan. \\ **Center for Environmental Science in Saitama, 914 Kamitanadare, Kazo, Saitama 347-0015, \\ Japan.
}

\begin{abstract}
A simple, low-cost filtration system composed of a ceramic filter, an iron net and iron bacterial sludge was developed to remove arsenic (As) from groundwater. The ceramic filter, made of an $80 \%$ clay soil and $20 \%$ rice bran mixture on a weight basis, was combined with the iron net and the iron bacterial sludge in a reactor, and the assembly (As removal filter) was tested for its ability to remove As from synthetic groundwater. Synthetic groundwater with a varying composition of $\mathrm{As}(\mathrm{III})$, ferrous iron (Fe(II)) and phosphate phosphorus (P) was filtered on a daily basis. The results showed that both Fe(II) in groundwater and those released from the iron net were oxidized biologically and/or physico-chemically and that As and P were effectively removed by adsorption and/or co-precipitation processes. The concentrations of $\mathrm{Fe}$ (II) and $\mathrm{P}$ in groundwater were decisive factors in the removal of As . Groundwater Fe concentrations of $\geq 2$ $\mathrm{mg} / \mathrm{L}$ and $\mathrm{P}$ concentrations of $\leq 3 \mathrm{mg} / \mathrm{L}$ with an $\mathrm{Fe} / \mathrm{P}$ molar ratio of $\geq 3.0$ were required to achieve an effluent As concentration of less than $50 \mu \mathrm{g} / \mathrm{L}$ from raw water containing $500 \mu \mathrm{g} / \mathrm{L}$ of As(III). This simple, inexpensive filter could be used to treat As in contaminated regions.
\end{abstract}

Keywords: arsenic removal, ceramic filter, groundwater, iron bacterial sludge, iron and phosphorus; iron net

\section{INTRODUCTION}

Arsenic (As) contamination in groundwater has caused a devastating health crisis all over the world, especially in Bangladesh and West Bengal, India (Dhar et al., 1997). In Bangladesh and other regions of the Indian subcontinent, 70 million people consume drinking water with As concentrations in excess of maximum contamination level (MCL) set by the World Health Organization (WHO, 1996) and US Environmental Protection Agency (USEPA, 2002) $(10 \mu \mathrm{g} / \mathrm{L})$ and by Bangladesh $(50 \mu \mathrm{g} / \mathrm{L})$. Ingestion of inorganic As can cause cancer of the skin, lung and bladder as well as noncancerous health problems (Mazumder et al., 1998; Smith et al., 1998). Arsenic in groundwater is mainly present in inorganic forms, such as arsenate $(\mathrm{As}(\mathrm{V}))$ and arsenite (As(III)). Arsenate is the predominant species in atmospheric conditions or in more oxidizing environments in the $\mathrm{pH}$ range of 6-9. It exists predominantly as oxyanions, such as $\mathrm{H}_{2} \mathrm{AsO}_{4}{ }^{-}$or $\mathrm{H}_{2} \mathrm{AsO}_{4}{ }^{2-}\left(\mathrm{HAsO}_{4}{ }^{2-}\right)$. Arsenite is thermodynamically stable and exists predominantly as $\mathrm{H}_{3} \mathrm{AsO}_{3}$ or $\mathrm{HAsO}_{2}$ under mildly reducing conditions. Arsenite, the most common species in anaerobic groundwater and the more toxic of the two forms (Pontius et al., 1994), is generally removed less efficiently than the oxidized As(V) (Dixit and Hering 2003). Arsenic release from subsurface minerals and sediments is the main cause of As contamination in groundwater (Chowdhury et al., 2000).

Different techniques for the removal of As from groundwater have been developed and tested. These include co-precipitation (e.g., with iron or aluminum salts), ion exchange,

Address correspondence to Jun Nakajima, Department of Environmental Systems Engineering,

Ritsumeikan University, Email: jnt07778@se.ritsumei.ac.jp

Received May 4, 2011, Accepted Jury 22, 2011. 
and adsorption by activated carbon and membrane processes (Kartinen and Martin, 1995). Most of these methods require a pre-oxidation step to transform As(III) into $\mathrm{As}(\mathrm{V})$. Arsenic removal by the application of dissolved Fe(II) and metal $\mathrm{Fe}(0)$ has received special attention due to the high removal efficiency of these treatments. Recent studies have shown that $\mathrm{As}(\mathrm{III})$ is partially oxidized to $\mathrm{As}(\mathrm{V})$ during the physicalchemical oxidation of dissolved Fe(II), resulting in a higher As removal efficiency than that obtained by direct addition of solid Fe(III) (Hug and Leupin, 2003; Roberts et al., 2004; Berg et al., 2006). Numerous studies of As removal by the application of $\mathrm{Fe}(0)$ have also been reported. In aerobic water, the slow, continuous release of dissolved $\mathrm{Fe}(\mathrm{II})$ from $\mathrm{Fe}(0)$ and the subsequent oxidation to solid $\mathrm{Fe}(\mathrm{III})$ effectively remove As (Su and Puls, 2001a, 2001b and 2003; Leupein and Hug, 2005; Lien and Wilkin, 2005).

Dissolved Fe(II) can be oxidized by both physical-chemical and biological processes, but the dominant process depends on the physical and chemical characteristics of the raw water and on the process conditions. Biological oxidation of dissolved Fe(II) in water is caused by several iron-oxidizing microorganisms such as Gallionella sp. and Leptothrix ochracea (Czekalla et al.,1985; Mounchet, 1992; Michalakos et al.,1997). The main product from the biological oxidation of dissolved Fe(II) is usually a poorly ordered iron oxide containing significant amounts of organic matter. Products from the intermixing of iron oxides, organic matter and bacteria exhibit unique metal retention properties (Ferris et al., 2000). Arsenic can directly adsorb onto the biological iron oxides. In addition, As(III) oxidation during biological oxidation of dissolved Fe(II) may occur (Katsoyiannis and Zouboulis, 2004; Shafiquzzaman et al., 2008).

Several small-scale As removal technologies have been applied in the field in Bangladesh (Khan et al., 2000; Hussam and Munir, 2007). Although these technologies have a high As removal efficiency, they also have certain drawbacks, including high cost and maintenance difficulties associated with the use of sand beds for filtration (Shafiquzzaman et al., 2009). In contrast, the ceramic filtration process, which uses porous ceramics (fired clay) to filter microbes or other contaminants from drinking water, has many potential advantages. Ceramic filters can be manufactured with locally available materials. They are low-cost, socially acceptable and can function with minimal maintenance (Chaudhuri et al., 1994; Oyanedel-Craver and Smith, 2008). Therefore, biological Fe(II) oxidation, co-precipitation with As and subsequent filtration through a simple ceramic filter instead of a sand bed could be a viable set of strategies for the removal of As from groundwater.

A locally made filter, called the soil ceramic candle, has been used in rural area of Bangladesh for the removal of iron $(\mathrm{Fe})$ from groundwater. The arsenic removal performance of this filter was evaluated, and a modification to the filter was proposed in our previous study (Shafiquzzaman et al., 2011). In this study, a simple, low-cost As removal filter composed of a ceramic filter, an $\mathrm{Fe}(0)$ net and iron bacterial sludge was developed and evaluated for its ability to remove As from synthetic groundwater containing varying compositions of $\mathrm{As}$ (III), Fe(II) and $\mathrm{P}$. The manufacturing procedure for the ceramic filter is described here in detail. 


\section{MATERIALS AND METHODS}

\section{Ceramic filter manufacturing and characterization}

Ceramic filters were manufactured by mixing $80 \%$ clay soil and $20 \%$ rice bran on a weight basis. The soil sample and the rice bran were collected from the local brick field and rice mill, respectively, of the southwestern region (Khulna) of Bangladesh. The soil sample was dried, ground with a hammer and passed through a $0.5 \mathrm{~mm}$ sieve. The rice bran was also dried and passed through a $1 \mathrm{~mm}$ sieve. A particle size distribution of the collected soil was measured by the laser diffraction method (Shimadzu SALD 3000, Japan). The mixing ratio of the ingredients was selected after testing the filtration flux and flexural strength of several ceramic bars prepared with different ratios of soil and rice bran. The filtration fluxes of ceramic bars made with $0 \%, 15 \%, 20 \%$ and $25 \%$ rice bran at $28.5 \mathrm{~cm}$ of water head were $0.11 \pm 0.02,0.16 \pm 0.01,0.53 \pm 0.08$ and $1.92 \pm$ $0.39 \mathrm{~mL} / \mathrm{cm}^{2} / \mathrm{min}$, respectively. The flexural strengths of the bars were $0.75 \pm 0.19,0.48$ $\pm 0.15,0.27 \pm 0.14$ and $0.08 \pm 0.01 \mathrm{kPa}$, respectively. The results indicated that fired ceramic bars with a higher percentage of rice bran $(25 \%)$ were low in strength and easily broken, while those with lower percentages $(10 \%$ and $15 \%)$ produced a relatively low filtration flux. On the basis of these results, a mixture of $80 \%$ soil and $20 \%$ rice bran was selected for ceramic filters in this study.

To manufacture the ceramic filters, soil and rice bran were combined and mixed until homogeneous. This dry mixture $(800 \mathrm{~g})$ was combined with water to make dough. The dough was then molded by hand, placed in a polyvinylchloride cylindrical mold $(10 \mathrm{~cm}$ diameter and $10 \mathrm{~cm}$ height), and compressed manually. The resulting cylindrical ceramic filters were hollow with one side open. The final ceramic filters had a height of $10 \mathrm{~cm}$ and a thickness of $2 \mathrm{~cm}$ (Fig. 1a). The filters were sun-dried for $48-72 \mathrm{~h}$ and then fired in a muffle furnace in the laboratory or in a small-scale pottery kiln in the field at $900^{\circ} \mathrm{C}$. The ceramic filter manufacturing cost was estimated to be $0.2-0.3$ USD per filter.

The apparent porosity of the ceramic filter was tested according to Yang et al. (2007). The pore size of the filter was estimated by comparing the particle size distribution of turbid waters (water with clay mixture) before and after filtration with a ceramic filter.

\section{Iron net ( $\mathrm{Fe}(0))$}

A commercially available iron net (with wire diameter of $0.75 \mathrm{~mm}$ ) was used without treatment as a source of $\mathrm{Fe}(0)$. The mean surface area and Fe content of the iron net were $654 \pm 28.4 \mathrm{~mm}^{2} / \mathrm{g}$ and $99-99.5 \%$, respectively. The iron net was cut, and the open cubic boxes $(11 \times 11 \times 11 \mathrm{~cm})$ were formed manually. These boxes were used to construct the As removal filter.

\section{Iron bacterial sludge}

Iron bacterial sludge was collected from natural river sediments (Ogure River, Gifu Prefecture, Japan.). Microscopic views of the bacterial sludge showed that the sediment mainly contained the Leptothrix ochracea iron oxidizing species with iron hydroxide flocs (image not shown). The collected sludge was cultured in the laboratory on a sand bed with a continuous tap water flow. Twenty-five milligrams of $\mathrm{FeSO}_{4} \cdot 7 \mathrm{H}_{2} \mathrm{O}$ diluted in $1 \mathrm{~L}$ of deionized water was fed daily onto the bed as the sole source of ferrous iron for bacterial growth. When required, sludge was taken from the bed, weighed on the basis 


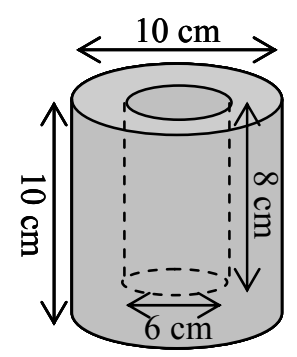

(a)

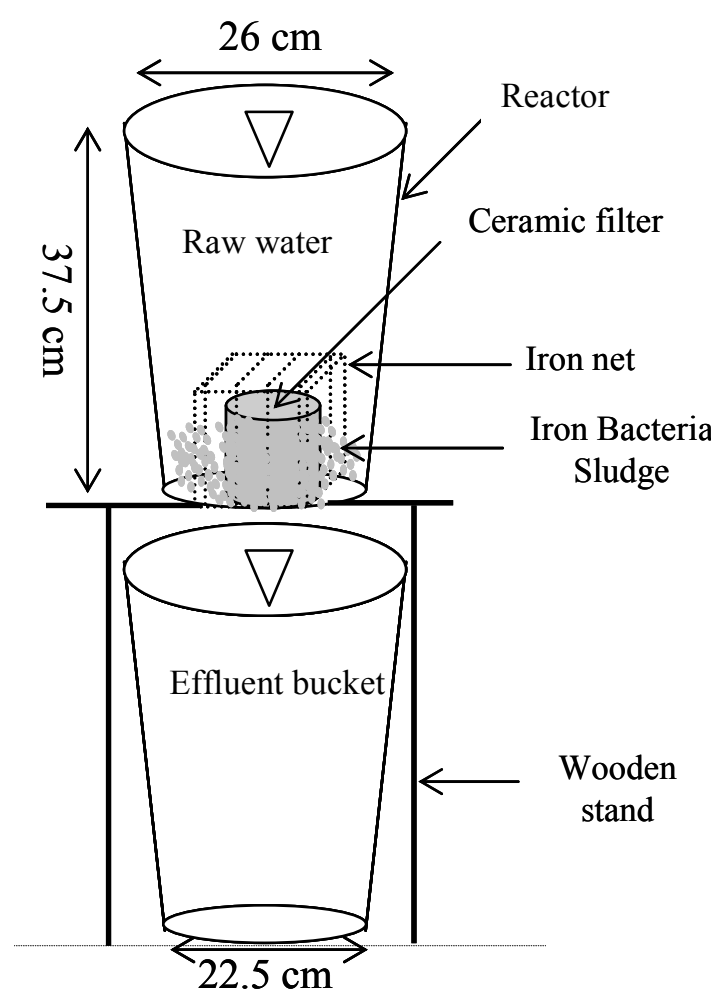

(b)

Fig. 1 - Schematic representation of (a) the ceramic filter and (b) the arsenic removal filter unit

of the suspended solids concentration $(\mathrm{mg} / \mathrm{L})$ and used for filtration experiments.

\section{Filter construction}

The As removal filter used to treat As in groundwater was composed of a reactor, a wooden stand and an effluent bucket (Fig. 1b). The reactor was a plastic bucket (15 L) with a small hole at the bottom to drain effluent water. The opening of the ceramic filter was affixed to the bottom of the reactor with acryl glue and covered with a cubic iron net box. Before starting each filtration experiment, the iron bacterial sludge was added to the reactor. The reactor was placed on the wooden stand, and the effluent bucket was positioned under the reactor.

\section{Stock solution}

The chemicals, all of which were reagent grade, were from either Wako, Japan, or Nacalai Tesque Inc., Kyoto, Japan. An As(III) stock solution (100 mg/L) was prepared by dissolving arsenic oxide $\left(\mathrm{As}_{2} \mathrm{O}_{3}\right)$ in deionized water with $5 \mathrm{ml} / \mathrm{L}$ of $\mathrm{HCl}$. An Fe(II) stock solution was prepared by dissolving $\mathrm{FeSO}_{4} \cdot 7 \mathrm{H}_{2} \mathrm{O}$ in deionized water immediately before the start of each experiment to avoid premature $\mathrm{Fe}(\mathrm{II})$ oxidation. A phosphorus (P) $(1000 \mathrm{mg} / \mathrm{L})$ stock solution was prepared by mixing reagent grade $\mathrm{K}_{2} \mathrm{HPO}_{4}$ with deionized water.

\section{Synthetic groundwater}

Synthetic groundwater, representing the geochemistry of Bangladesh groundwater, was prepared in the laboratory by dissolving the appropriate chemicals (Table 1) (BGS and 
DPHE, 2001). Each liter of synthetic groundwater consisted of $10 \mathrm{mg}$ of $\mathrm{NH}_{4} \mathrm{Cl}, 500$ $\mathrm{mg}$ of $\mathrm{MgSO}_{4} \cdot 7 \mathrm{H}_{2} \mathrm{O}, 1.2 \mathrm{mg}$ of $\mathrm{NaCl}, 400 \mathrm{mg}$ of $\mathrm{CaCl}_{2} \cdot 2 \mathrm{H}_{2} \mathrm{O}, 2 \mathrm{mg}$ of $\mathrm{MnSO}_{4} \cdot 5 \mathrm{H}_{2} \mathrm{O}$ and $500 \mathrm{mg}$ of $\mathrm{NaHCO}_{3}$. Synthetic groundwater with varying compositions of $\mathrm{As}$ (III), $\mathrm{Fe}(\mathrm{II})$ and $\mathrm{P}$ was prepared by diluting stock solutions prior to each filtration experiment. The $\mathrm{pH}$ value was adjusted to 7.0 - 7.4 for every series of experiments by adding sodium hydroxide or hydrochloric acid.

\section{Filtration experiments}

In the filtration experiments, $14 \mathrm{~L}$ of synthetic groundwater containing the compounds of interest (Table 2) was poured daily into the reactor. The water flowed gravitationally through the filter for $4-6 \mathrm{~h}$. The iron net and the ceramic filter in the reactor were fully immersed during the filtration period $(4-6 \mathrm{~h})$ and partially immersed during the remaining $18-20 \mathrm{~h}$ of the day. Effluent water was sampled daily from the effluent bucket. The redox potential (ORP), dissolved oxygen (DO), $\mathrm{pH}$ and flow rate were measured daily. Samples were kept in the refrigerator at $4^{\circ} \mathrm{C}$ until the As, Fe and $\mathrm{P}$ analyses. A total of 17 series of experiments were conducted (Runs 1 - 17) to assess the As(III) removal performance (Table 2). All laboratory experiments were focused on the removal of As(III), because As(III), the most common arsenic species in groundwater, is generally removed less efficiently than the oxidized As(V) (Dixit and Herring, 2003).

Table 1 - Composition of synthetic groundwater used in this study and Bangladesh groundwater as obtained from BGS data base (BGS and DPHE, 2001)

\begin{tabular}{ccc}
\hline & Synthetic groundwater & Bangladesh groundwater \\
\hline $\mathrm{pH}$ & $7.5 \pm 0.5$ & $7.0 \pm 0.2$ \\
$\mathrm{Ca}(\mathrm{mg} / \mathrm{L})$ & 100 & $77 \pm 56$ \\
$\mathrm{Mg}(\mathrm{mg} / \mathrm{L})$ & 40 & $31 \pm 20$ \\
$\mathrm{Fe}(\mathrm{mg} / \mathrm{L})$ & $0-5$ & $5.4 \pm 4.8$ \\
$\mathrm{As}(\mu \mathrm{g} / \mathrm{L})$ & 500 & $200 \pm 167$ \\
$\mathrm{P}(\mathrm{mg} / \mathrm{L})$ & $0.9-10$ & $1.5 \pm 1.48$ \\
$\mathrm{Mn}(\mathrm{mg} / \mathrm{L})$ & 0.45 & $0.6 \pm 0.7$ \\
\hline
\end{tabular}

Table 2 - Experimental details

\begin{tabular}{cccccc}
\hline $\begin{array}{c}\text { Experimental } \\
\text { Runs }\end{array}$ & $\begin{array}{c}\mathrm{As}(\mathrm{III}) \\
(\mu \mathrm{g} / \mathrm{L})\end{array}$ & $\begin{array}{c}\mathrm{Fe}(\mathrm{II}) \\
(\mathrm{mg} / \mathrm{L})\end{array}$ & $\begin{array}{c}\mathrm{P} \\
(\mathrm{mg} / \mathrm{L})\end{array}$ & $\begin{array}{c}\mathrm{Fe}(0) \text { net } \\
(\mathrm{g})\end{array}$ & $\begin{array}{c}\text { Iron bacterial } \\
\text { sludge }(\mathrm{mg})\end{array}$ \\
\hline Run 1 & 500 & 5 & 0.9 & 87 & 160 \\
Run 2 & 500 & 5 & 0.9 & - & 160 \\
Run 3 & 500 & 5 & 5 & 300 & 160 \\
Run 4 & 500 & 5 & 0.9 & 300 & 750 \\
Run 5 & 500 & 5 & 0.9 & 300 & 1500 \\
Run 6 & 500 & 5 & 0.9 & 300 & 5000 \\
Run 7-17 & 500 & $0-5$ & $0.9-10$ & 600 & 5000 \\
\hline
\end{tabular}

Run 1-3 were carried out for 70 days and Run 4 - 17 were carried out for 14 days. 


\section{Analytical method}

Arsenic was analyzed using a polarized Zeeman GFAAS (atomic adsorption spectrophotometer) (Hitachi Z2700, Japan) or an ICP-MS (inductively coupled plasma mass spectrometry) (Yokogawa, HP 4500, Japan). The total Fe concentration was measured using ICP spectrometry (Seiko SPS 4000, Japan). Phosphate was measured with the molybdenum blue colorimetric method (JEMAI, 2008). The $\mathrm{pH}$, ORP and DO were measured with a $\mathrm{pH}$ meter (HORIBA-D-54S, Japan), an ORP meter (HORIBA-D54S, Japan) and a DO meter (HACH-HQ30d, Japan), respectively.

\section{RESULTS AND DISCUSSION Soil and filter characteristics}

The particle size distribution of the soil sample showed that the soil used in the ceramic filters contained approximately $40 \%$ sand, $52 \%$ silt and $8 \%$ clay. The porosity and pore size of the filter were $60 \% \pm 1 \%$ and $1-5 \mu \mathrm{m}$, respectively.

\section{$\mathrm{As}(\mathrm{III}), \mathrm{Fe}(\mathrm{II})$ and $\mathrm{P}$ removal}

The efficiency of As(III) removal with and without the iron net was investigated in Run 1 and Run 2 (Fig. 2a). As shown in Fig. 2a, the As(III) removal efficiency was clearly higher in Run 1 (with the iron net) than in Run 2 (without the iron net). In Run 1, As(III) was removed gradually from $500 \mu \mathrm{g} / \mathrm{L}$ to $50 \mu \mathrm{g} / \mathrm{L}$ over 20 days. After 20 days, As in the effluent decreased below $50 \mu \mathrm{g} / \mathrm{L}$. In contrast, removal was insufficient in Run 2, with a constant effluent As concentration of $120 \mu \mathrm{g} / \mathrm{L}$ after 20 days. The concentration of effluent Fe is shown in Fig. 2b. According to the figure, less than $0.4 \mathrm{mg} / \mathrm{L}^{-1}$ of total Fe was present in the effluent on the first day, and this concentration remained constant throughout both runs. In contrast to As, the $\mathrm{P}$ concentration was effectively reduced from an initial concentration of $0.9 \mathrm{mg} / \mathrm{L}$ to less than $0.3 \mathrm{mg} / \mathrm{L}$ (Fig. 2c).

The $\mathrm{pH}$ of the effluent (7.5 - 7.7) was slightly higher than that of the influent (7.0 - 7.4) in both runs. This expected $\mathrm{pH}$ increase was attributed to water decomposition by the iron net and to the sorption reaction of arsenic, which releases $\mathrm{OH}^{-}$groups from sorbents as a result of ligand exchange ( $\mathrm{Su}$ and Puls, 2001a). The influent ORP values, which ranged from -50 to $-150 \mathrm{mV}$, indicated that $\mathrm{Fe}$ in the synthetics groundwater exists as dissolved $\mathrm{Fe}(\mathrm{II})$. The effluent ORP $(100-200 \mathrm{mV})$ was more oxidizing than that of the influent $(-50$ to $-150 \mathrm{mV})$. The DO levels of the influent $(9 \pm 1 \mathrm{mg} / \mathrm{L})$ and effluent $(8 \pm$ $1 \mathrm{mg} / \mathrm{L})$ indicated oxidation in the reactor. The flow rate remained nearly constant $(3.5$ $\pm 0.5 \mathrm{~L} / \mathrm{h}$ for Run 1 and $2.9 \pm 0.5 \mathrm{~L} / \mathrm{h}$ for Run 2$)$ throughout the operation $(70 \mathrm{~d})$, indicating that the filters were not clogged. Roughly $60-70 \mathrm{~L} / \mathrm{d}$ of water, an adequate amount to supply the drinking and cooking water needs of a middle-sized family of 5 - 6 people in a developing country (Shafiquzzaman et al., 2009), could be treated at this flow rate.

\section{Effect of iron bacterial sludge on As(III) removal in early phase}

In field applications, As concentrations must be reduced below the Bangladesh drinking water standard $(50 \mu \mathrm{g} / \mathrm{L})$. Results from Run 1 (Fig. 2a) indicated that roughly 20 days were required to reach As concentrations below this limit. This may have been a result of insufficient iron in the reactor during the initial phase of operation. Therefore, As(III) removal was examined by increasing the initial amount of iron bacterial sludge in Runs 


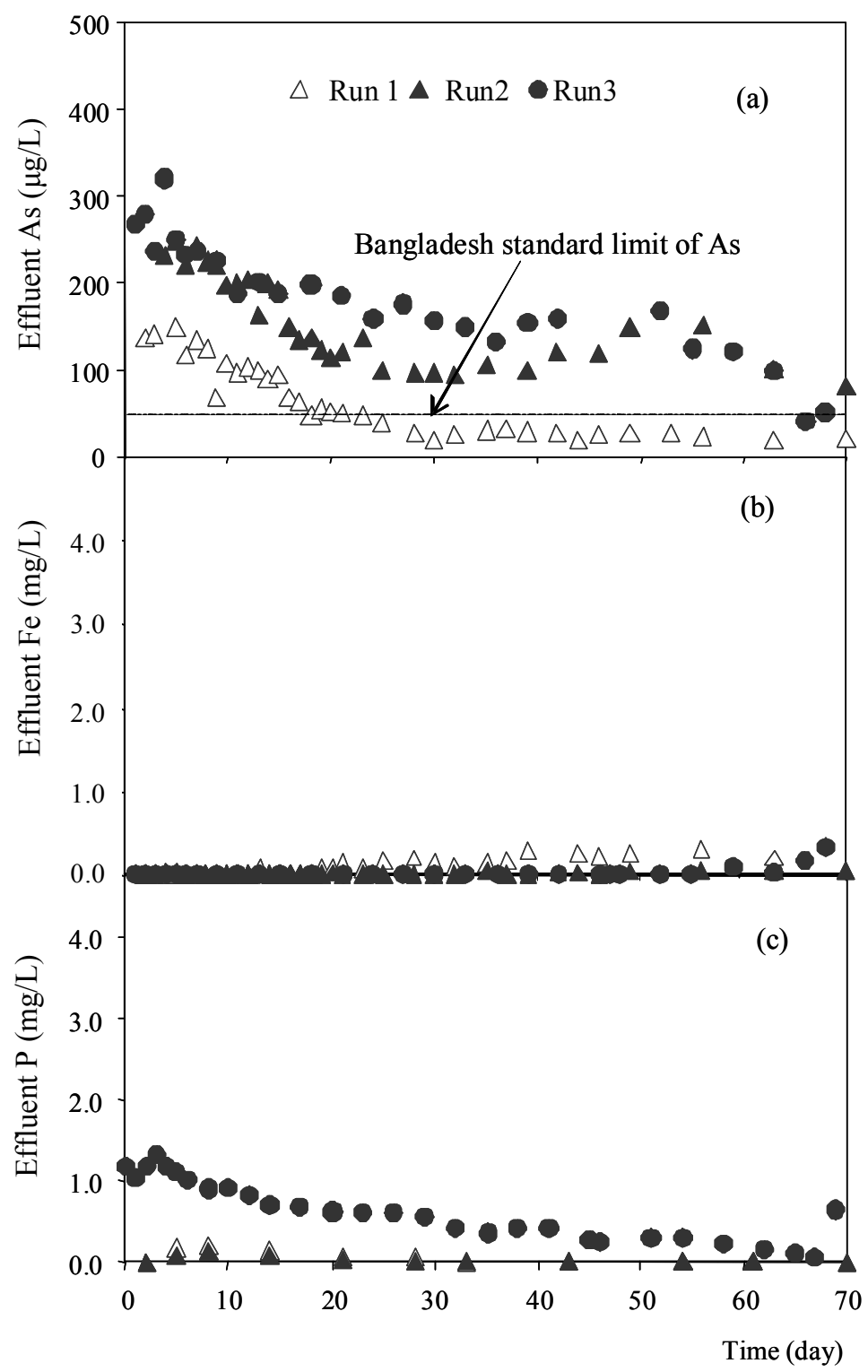

Fig. 2 - Removal of (a) A(III), (b) Fe and (c) P by the arsenic removal filter

4, 5 and 6. Initially, 750, 1,500 and 5,000 $\mathrm{mg}$ of iron bacterial sludge was added for Runs 4, 5 and 6, respectively (Table 2). The corresponding effluent As concentrations of less than $50 \mu \mathrm{g} / \mathrm{L}$ were achieved at 13, 6 and 1 days of operation, for Runs 4, 5 and 6, respectively (Fig. 3), and these results suggested that iron bacterial sludge added at the beginning of the experiment played an important role in the early phase of filter operation. Iron bacterial sludge contains biomass with biological iron hydroxides. Increasing the amount of this bacterial sludge substantially increases the amount of biogenic iron hydroxides, resulting in faster reduction of As concentration to less than $50 \mu \mathrm{g} / \mathrm{L}$ in the effluent water. Thus, it was demonstrated that 5,000 $\mathrm{mg}$ of iron bacterial sludge should be added to the filter assembly.

\section{Effect of $P$}

The effect of P on As(III) removal was examined in Run 3 (Fig. 2a). As shown in this figure, $5 \mathrm{mg} / \mathrm{L}$ of $\mathrm{P}$ as phosphate caused a significant decrease in As(III) removal. The 


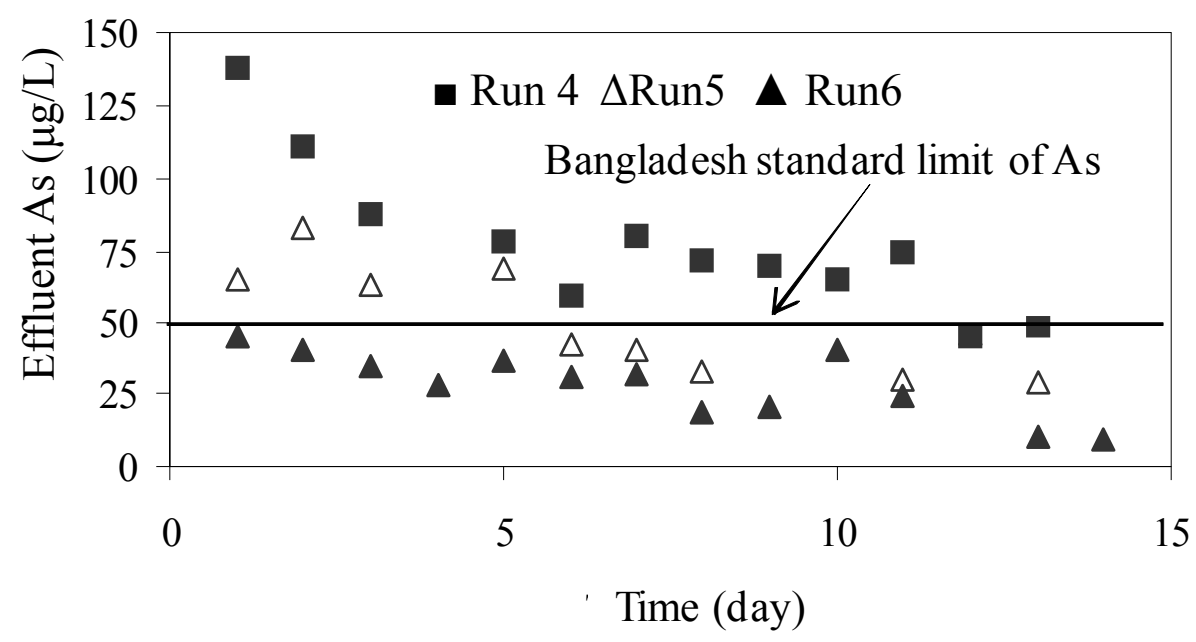

Fig. 3 - Effects of iron bacterial sludge added at the start of the experiment

average effluent As concentration was $192 \pm 55 \mu \mathrm{g} / \mathrm{L}$. The removal efficiency was reduced by $25 \%$ from Run 1 to Run 3 due to higher $\mathrm{P}$ concentrations in the synthetic groundwater. As expected, $\mathrm{P}$ was also reduced to an average of $1.0 \pm 0.37 \mathrm{mg} / \mathrm{L}$ in Run 3 (Fig. 2c). Arsenate and $\mathrm{P}$ have similar chemical properties and are known as innersphere complex-forming anions that are strongly sorbed to mineral surfaces such as $\mathrm{Fe}$ oxides (Su and Puls, 2001a and 2003). In our study, a partial oxidation of As(III) to As(V) might occur (will be discussed later), therefore the decrease in As(III) removal in the presence of phosphate was primarily due to competition of oxidized $\mathrm{As}(\mathrm{V})$ and $\mathrm{P}$ for sorption sites on the precipitated iron hydroxides surfaces. Moreover, the decrease in As removal might also have been caused by a decrease in the corrosion of the $\mathrm{Fe}(0)$ net, because phosphate is known to act as a corrosion inhibitor of $\mathrm{Fe}(0)$ (Armstrong et al., 1994). This phenomenon was investigated through batch experiments, and results showed that corrosion of the iron net decreased as the $\mathrm{P}$ concentration in the solution increased (data not shown).

\section{Effect of $F e(I I)$ and $P$ composition in groundwater}

To determine the levels of $\mathrm{Fe}(\mathrm{II})$ and $\mathrm{P}$ in synthetic groundwater beyond which As would be reduced to less than the Bangladesh limit $(50 \mu \mathrm{g} / \mathrm{L})$, several series of filtration experiments (Runs 7 - 17) were conducted. Fig. 4 shows the effluent As concentration under different $\mathrm{Fe}$ and $\mathrm{P}$ concentrations in synthetic groundwater. As shown in Fig. 4a, the effluent As concentration decreased linearly as Fe(II) increased. The As(III) decreasing rate constant was found to be $34.4 \mu \mathrm{g} / \mathrm{mg}$ with an $\mathrm{r}^{2}$ value of 0.998 . According to Fig. 4a, an effluent As concentration of less than $50 \mu \mathrm{g} / \mathrm{L}$ can be obtained if the groundwater contains at least $2 \mathrm{mg} / \mathrm{L}$ of Fe(II) and $0.9 \mathrm{mg} / \mathrm{L}$ of $\mathrm{P}$. In contrast, the effluent As concentration increased linearly as the $\mathrm{P}$ concentration in the raw water increased (Fig. 4b). The rate constant was found to be $44 \mu \mathrm{g} / \mathrm{mg}$ with an $\mathrm{r}^{2}$ value of 0.991 . 


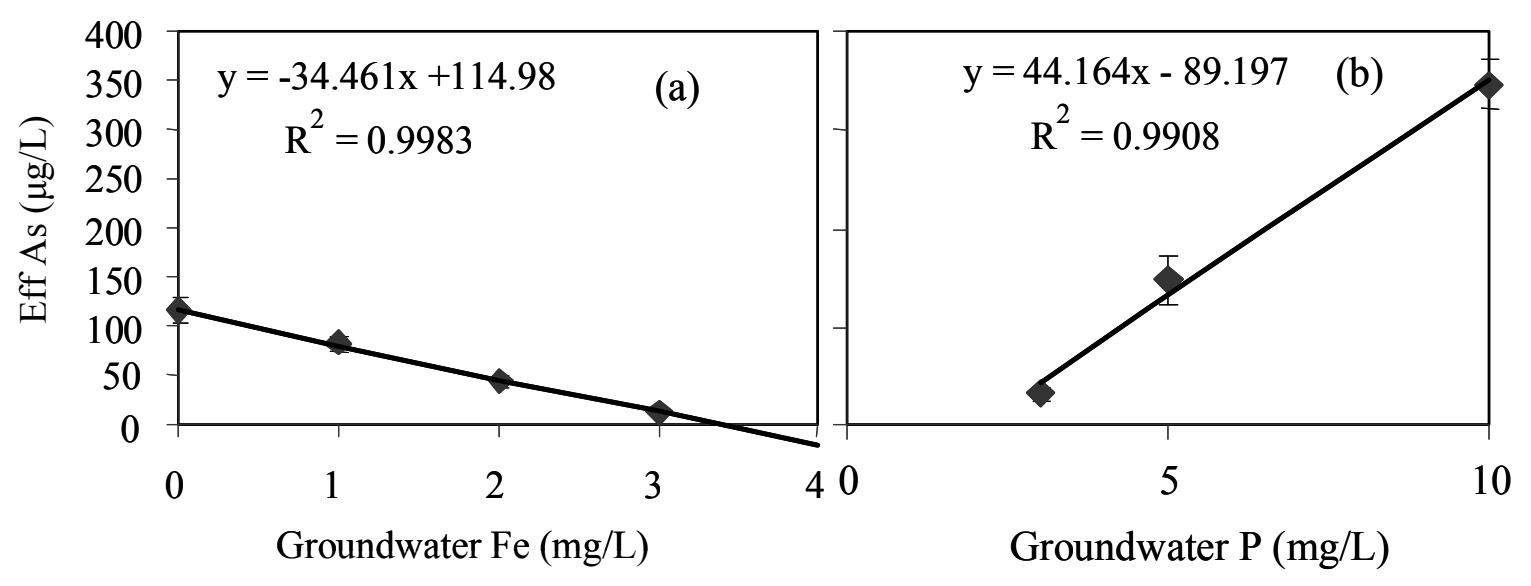

Fig. 4 - (a) Effluent As concentration as a function of $\mathrm{Fe}(\mathrm{II})$ in synthetic groundwater. $\mathrm{P}=0.9 \mathrm{mg} / \mathrm{L}$.

(b) Effluent As concentration as a function of $\mathrm{P}$ in synthetic groundwater. $\mathrm{Fe}(\mathrm{II})=5 \mathrm{mg} / \mathrm{L}$. Error bars show the standard deviation of 14 day samples

Based on the best fit line for the measured effluent As concentrations shown in Fig. 4a and $4 \mathrm{~b}$, the following empirical equation (Eq. (1)) was derived by a multiple regression analysis to estimate the As removal efficiency from the concentrations of dissolved Fe and $\mathrm{P}$ in synthetic groundwater.

As removal $(\mu \mathrm{g} / \mathrm{L})=33(\mu \mathrm{g} / \mathrm{mg}) \times \mathrm{Fe}(\mathrm{mg} / \mathrm{L})-45(\mu \mathrm{g} / \mathrm{mg}) \times \mathrm{P}(\mathrm{mg} / \mathrm{L})+430(\mu \mathrm{g} / \mathrm{L})$

Arsenite removal and the corresponding effluent As concentrations calculated with this empirical equation for different scenarios (different concentrations of $\mathrm{Fe}$ and $\mathrm{P}$ in the synthetic groundwater) agreed well with measured experimental values as shown in Fig. 5. According to this figure, an effluent As concentration of less than $50 \mu \mathrm{g} / \mathrm{L}$ can be obtained if the initial composition of synthetic groundwater is as follows: $500 \mu \mathrm{g} / \mathrm{L}$ of $\mathrm{As}(\mathrm{III}), 2 \mathrm{mg} / \mathrm{L}$ or more of $\mathrm{Fe}(\mathrm{II}), 3 \mathrm{mg} / \mathrm{L}$ or less of $\mathrm{P}$ and an $\mathrm{Fe} / \mathrm{P}$ molar ratio of at least 3. A comprehensive database of groundwater composition in Bangladesh showed that the average As, Fe and $\mathrm{P}$ concentrations are $199 \pm 166 \mu \mathrm{g} / \mathrm{L}, 5.3 \pm 4.8 \mathrm{mg} / \mathrm{L}$ and $1.47 \pm$ $1.48 \mathrm{mg} / \mathrm{L}$, respectively (BGS and DPHE, 2001). According to this database, our As removal filter would be applicable for this range of groundwater compositions. This study did not consider the influence of other geochemical compounds in groundwater, such as silicate, sulfate and dissolved organic matter. We plan to conduct additional experiments on the influence of such compounds on As removal by our filter. We will also conduct experiments with actual groundwater for a long-term assessment. Furthermore, bacterial (pathogen) contamination of the effluent will also be measured and reported to ensure the microbiological quality of the filtered water.

\section{As(III) removal mechanism}

The efficient removal of As by the application of zero valent iron $(\mathrm{Fe}(0))$ has been reported in many studies. In $\mathrm{Fe}(0)$ applications, adsorption, surface precipitation and coprecipitation of As with the corrosion products have been reported as possible mechanisms of As removal (Su and Puls, 2001a and 2001b; Manning and Amrhein, 2002; Leupin and Hug, 2005). In addition, the dissolved iron present in groundwater as 

$\mathrm{P}=0.9 \mathrm{mg} / \mathrm{L}$
$\mathrm{P}=2 \mathrm{mg} / \mathrm{L}$
$\mathrm{P}=3 \mathrm{mg} / \mathrm{L}$
$\triangle \mathrm{P}=4 \mathrm{mg} / \mathrm{L}$
$\mathrm{OP}=5 \mathrm{mg} / \mathrm{L}$

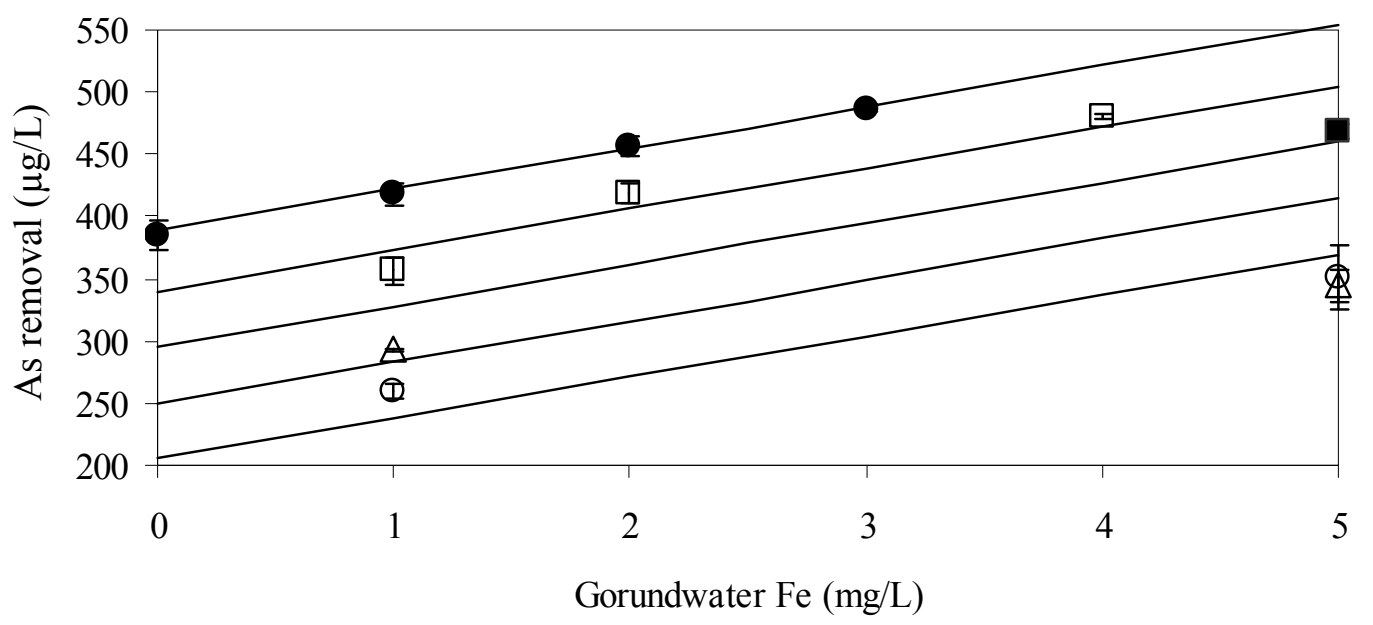

Fig. 5 - Measured (symbol) and calculated (solid line) concentrations of As in the filter effluent at varying concentrations of $\mathrm{Fe}$ and $\mathrm{P}$ in synthetic groundwater. Error bars show the standard deviation of 14 day samples

Fe(II) plays a significant role in As removal (Hug and Leupin, 2003; Roberts et al., 2004; Berg et al., 2006). In our filter experiments, less than $0.4 \mathrm{mg} / \mathrm{L}$ of Fe was present in the effluent of Runs 1 and 2 (Fig. 2b), indicating that most of the Fe(II) in synthetic groundwater as well as that released by corrosion of the iron net was rapidly oxidized by biological and/or physical-chemical processes and filtered by the ceramic filter. Based on our experimental conditions, the mean values of $\mathrm{pH}$ and ORP in the influent water were $7.0-7.4$ and -50 to $-150 \mathrm{mV}$, respectively, throughout the experiment. Although these values of $\mathrm{pH}$ and ORP in the influent are close to the boundary line of biological $\mathrm{Fe}(\mathrm{II})$ oxidation zone in the Eh-pH diagram, they are also present in the competition zone between biotic and abiotic Fe(II) oxidation (Mounchet, 1992). Therefore, the experimental conditions of this study suggested that both biological and/ or physico-chemical oxidation of dissolved $\mathrm{Fe}(\mathrm{II})$ in the reactor might occur. Furthermore, the average influent values for ORP $(-50$ to $-150 \mathrm{mV})$ and $\mathrm{pH}(7.0-7.4)$ indicated ion species $\left(\mathrm{Fe}^{2+} / \mathrm{Fe}(\mathrm{OH})_{2}\right)$ in equilibrium. Increasing the ORP value to $100-$ $200 \mathrm{mV}$ and the $\mathrm{pH}$ to $7.5-7.7$ in the effluent water changed the equilibrium towards oxidizing conditions in which $\mathrm{Fe}(\mathrm{OH})_{3}(\mathrm{aq})$ is the predominant species. Therefore, the oxidized iron in the reactor would exist as poorly ordered iron oxides such as $\mathrm{Fe}(\mathrm{OH})_{3}$ and hydrous ferric oxides (HFO) (e.g., $\left(\mathrm{Fe}_{2} \mathrm{O}_{3}, 2-3 \mathrm{H}_{2} \mathrm{O}\right)$ ) (Snoeyink and Jenkins, 1980; Katsoyiannis and Zouboulis, 2002 and 2004). It is well known that amorphous $\mathrm{Fe}(\mathrm{OH})_{3}, \mathrm{HFO}$ and Goethite bind both arsenite (As(III)) and arsenate (As(V)) (Manning et al., 1998; Hug and Leupin, 2003). In contrast, the oxidation of As(III) parallel to the biological and/or physico-chemical oxidation of $\mathrm{Fe}$ (II) may occur in the reactor and further enhance the overall As removal efficiency (Katsoyiannis et al., 2002; Katsoyiannis and Zouboulis, 2004; Leupin and Hug, 2005; Shafiquzzaman et al., 2008). Moreover, the gradual decrease of effluent As concentration in Runs 1 and 2 (Fig. 2b) was caused by the accumulation of Fe hydroxides in the reactor. The results were consistent with the results of As removal efficiency by changing the amount of iron bacterial sludges (Fig. 3). The possible physico-chemical and biological reactions during the filtration process in our filter are shown in Table 3. 
Table 3 - Possible physico-chemical and biological reactions during the filtration process

\begin{tabular}{|c|c|c|}
\hline Phenomena & Reactions & References \\
\hline $\begin{array}{l}\mathrm{Fe}(\mathrm{II}) \text { release from } \mathrm{Fe}(0) \\
\text { net corrosion }\end{array}$ & $\mathrm{Fe}(0)+2 \mathrm{H}_{2} \mathrm{O}+1 / 2 \mathrm{O}_{2} \rightarrow \mathrm{Fe}(\mathrm{II})+\mathrm{H}_{2} \mathrm{O}+2 \mathrm{OH}^{-}$ & Leupin and Hug, 2005 \\
\hline $\begin{array}{l}\text { Oxidation of released } \\
\mathrm{Fe}(\mathrm{II}) \text { and naturally } \\
\text { occurring Fe(II) }\end{array}$ & $\mathrm{Fe}(\mathrm{II})+2 \mathrm{H}_{2} \mathrm{O}+1 / 2 \mathrm{O}_{2} \stackrel{\text { Iron bacteria }}{\rightarrow} \mathrm{Fe}(\mathrm{III})+1 / 2 \mathrm{H}_{2} \mathrm{O}+\mathrm{OH}^{-}$ & $\begin{array}{l}\text { Katsoyiannis et al., 2002; } \\
\text { Katsoyiannis and } \\
\text { Zouboulis, 2004; Leupin } \\
\text { and Hug, 2005 }\end{array}$ \\
\hline $\begin{array}{l}\text { Physico-chemical } \\
\text { oxidation of As(III) }\end{array}$ & $\begin{array}{c}\mathrm{As}(\mathrm{III})+\text { Intermediate }\left(\left({ }^{\circ} \mathrm{O}_{2} \cdot \mathrm{OH}, \mathrm{Fe}(\mathrm{IV})\right) \rightarrow \mathrm{As}(\mathrm{IV})\right. \\
\mathrm{As}(\mathrm{IV})+\mathrm{O}_{2} \rightarrow \mathrm{As}(\mathrm{V})+{ }^{\cdot} \mathrm{O}_{2}^{-}\end{array}$ & Leupin and Hug, 2005 \\
\hline $\begin{array}{l}\text { Biological oxidation of } \\
\text { As(III) }\end{array}$ & $\mathrm{As}(\mathrm{III})+\mathrm{O}_{2} \stackrel{\text { Iron bacteria }}{\rightarrow} \mathrm{As}(\mathrm{V})$ & $\begin{array}{c}\text { Katsoyiannis et al., 2002; } \\
\text { Katsoyiannis and } \\
\text { Zouboulis, 2004; } \\
\text { Shafiquzzaman et al., } \\
2008\end{array}$ \\
\hline $\begin{array}{l}\text { Surface complexion and } \\
\text { precipitation of As }\end{array}$ & $\begin{array}{l}\mathrm{Fe}(\mathrm{III})+3 \mathrm{H}_{2} \mathrm{O} \rightarrow \underset{\mathrm{Fe}(\mathrm{OH})_{3}+3 \mathrm{H}^{-}}{\rightarrow} \rightarrow \overrightarrow{\mathrm{Fe}}(\mathrm{OH})_{3}+\mathrm{As} \rightarrow \mathrm{Fs} \text { complex }+\mathrm{H}_{2} \mathrm{O}\end{array}$ & $\begin{array}{c}\text { Katsoyiannis et al., 2002; } \\
\text { Katsoyiannis and } \\
\text { Zouboulis, 2004; Leupin } \\
\text { and Hug, 2005 } \\
\text { Shafiquzzaman et al., } \\
2008\end{array}$ \\
\hline
\end{tabular}

\section{Filter maintenance and cleaning}

Filtration experiment data showed that clogging of the filter did not occur during the 70 days of operation. Therefore, minimal maintenance would be required for the novel ceramic filter in comparison with sand filtration. For example, scrubbing the ceramic filter with a soft brush or cloth would restore its filtration capacity when clogging reduces the flow rate to an unsatisfactory level (Shafiquzzaman et al., 2011). The sludge collected in the reactor should be removed periodically (once a month) to ensure a satisfactory flow rate. When the sludge is removed, a portion $(5,000 \mathrm{mg})$ should be retained and added back to the reactor. The iron net should be replaced at the end of its useful life span. The life span was estimated with isotherm data for As(III) removal by the iron net and the average groundwater composition in Bangladesh. The As(III) adsorption capacity of the iron net was found to be $1630 \mu \mathrm{g} / \mathrm{g}$ (Shafiquzzaman et al., 2011). Based on the isotherm data, the filter could be used for approximately 1 year at a flow rate of $60 \mathrm{~L} / \mathrm{d}$ with influent water containing $400 \mu \mathrm{g} / \mathrm{L}$ of As, $5 \mathrm{mg} / \mathrm{L}$ of Fe(II) and $1 \mathrm{mg} / \mathrm{L}$ of P before As breakthrough (MCL of $50 \mu \mathrm{g} / \mathrm{L}$ ) occurred.

\section{Practical implications}

The filter proposed in this study could serve as a simple, low-cost treatment technique. All filter materials are locally available at little to no cost, and the manufacturing procedure is simple and easy. The iron bacterial sludge could be found in many ironrich areas, or the sludge could be produced in the operational filter unit. The As removal filter unit (including ceramic filter, iron net, reactor and effluent bucket) cost was estimated at 7 - 8 USD, an affordable price for rural households in developing countries. Furthermore, the unit cost could be reduced to $4-5$ USD if clay pot is used instead of plastic bucket for the reactor and effluent bucket. The estimated cost is nearly 10 times 
less than that of the SONO arsenic filter (Hussam and Munir, 2007). The only operation and maintenance cost is the annual replacement of the iron net or the ceramic filter, which is estimated to be between 0.5 and 1 USD. In the absence of manufacturing defects, the filter will produce potable water for at least 1 year.

\section{Filter sludge management}

The release of As from the sludge produced in our filter was examined with TCLP (toxicity characteristic leaching procedure) leachant containing $0.1 \mathrm{~mol} / \mathrm{L}$ of acetic acid and $0.064 \mathrm{~mol} / \mathrm{L}$ of $\mathrm{NaOH}$ (USEPA, 1986). The results showed that leachate concentrations of As did not exceed either the maximum USEPA or the Australian TCLP leachate values of 5,000 and $300 \mu \mathrm{g} / \mathrm{L}$, respectively (data not shown). Therefore, the sludge produced in the reactor would not be classified as hazardous waste material. However, important factors, such as $\mathrm{pH}$ and redox potential, that were not accounted for in the TCLP analysis may lead to an inaccurate estimate of As leaching in the solid wastes (Meng et al., 2001; Shafiquzzaman et al., 2010). To minimize this possible risk, sludge should be kept away from children and discarded into deep pits encased in concrete.

\section{CONCLUSIONS}

This study introduced a simple, effective filter assembly for As removal composed of a ceramic filter, an iron net and iron bacterial sludge, and its efficacy was tested in removing As from synthetic groundwater containing varying compositions of As(III), $\mathrm{Fe}(\mathrm{II})$ and $\mathrm{P}$. The main findings from this study include the following:

1. Arsenite $(\mathrm{As}(\mathrm{III}))$ was removed by adsorption and/or co-precipitation with the Fe precipitate.

2. Significant removal of dissolved Fe and P (over 95\%) was achieved simultaneously.

3. Initial seeding with iron bacterial sludge played an important role in the early phase of treatment and quickened the production of an effluent with less than $50 \mu \mathrm{g} / \mathrm{L}$ of As.

4. The efficiency of As(III) removal depended on the concentrations of Fe and P in groundwater.

5. An Fe/P molar ratio of at least 3 with an Fe concentration of greater than or equal to 2 $\mathrm{mg} / \mathrm{L}$ and a $\mathrm{P}$ concentration of less than or equal to $3 \mathrm{mg} / \mathrm{L}$ were required to achieve an effluent As concentration of less than $50 \mu \mathrm{g} / \mathrm{L}$ by the filter.

6. This simple, inexpensive filter can be made with locally available materials and can be used to treat As in contaminated waters.

Field-level experiments with groundwater from Bangladesh will be conducted and reported to assess the long-term viability of the filter.

\section{ACKNOWLEDGEMENTS}

The authors would like to thank the Japan Society for the Promotion Science (JSPS) for the financial support of this research. The assistance of Fumiaki Kakijuka in laboratory experiments is also gratefully acknowledged. 


\section{REFERENCES}

Armstrong R. D., Peggs L. and Walsh A. (1994) Behavior of sodium silicate and sodium phosphate (tribasic) as corrosion inhibitors for iron, J. Appl. Electrochem., 24, 12441248.

Berg M., Luzi S., Trang P. T. K., Viet P. H., Giger W. and Stuben D. (2006) Arsenic removal from groundwater by household sand filters: Comparative field study, model calculations and health benefits, Environ. Sci. Technol., 40, 5567-5573.

BGS, DPHE (2001) Arsenic contamination in groundwater in Bangladesh, Volume 2; Kinniburgh, D. G., Smedley, P. L., Eds.: Final report, Brtish Geological survey report Wc/00/19; British Geological Survey: Keyworth, UK.

Chaudhuri M., Verma S. R. and Gupta A. (1994) A performance evaluation of ceramic filter candles, J. Environ. Eng., 120, 1646-1651.

Chowdhury U. K., Biswas B. K., Chowdhury T. R., Samanta G., Mandal B. K., Basu G. C., Chanda C. R., Lodh D., Saha K. C., Mukherjee S. K., Roy S., Kabir S., Quamruzzaman Q. and Chakraborti D. (2000) Groundwater arsenic contamination in Bangladesh and West Bengal, India, Environ. Health Prespect., 108, 393-397.

Czekalla C., Mevious W. and Henert H. (1985) Quantitative removal of iron and manganese by microorganisms in rapid sand filters (in situ investigations), Water Supply, 3, 111-123.

Dhar R. K., Biswas B. K., Samanta G., Mandal B. K., Chakraborti D., Roy S., Jafar A., Islam A., Ara G., Kabir S., Khan A. W., Ahmed S. A. and Hadi S. A. (1997) Groundwater arsenic calamity in Bangladesh, Current Sci., 73, 8-58.

Dixit S. and Hering J. G. (2003) Comparison of arsenic (V) and arsenic (III) sorption onto iron oxides minerals: Implications for arsenic mobility, Environ. Sci. Technol., 37, 4182-4189.

Ferris F. G., Hallberg R. O., Lyven B. and Pederson K. (2000) Retention of stortium, cesium, lead and uranium by bacterial iron oxides from subterranean environment, Appl. Geochem., 15, 1035-1042.

Hug S. J. and Leupin O. X. (2003) Iron-catalyze oxidation of arsenic (III) by oxygen and by hydrogen: pH-dependant formation of oxidants in the fenton reaction, Environ. Sci. Technol., 37, 2734-2742.

Hussam A. and Munir A. K. M. (2007) A simple and effective arsenic filter based on composite iron matrix: Development and deployment studies from groundwater of Bangladesh, J. Environ. Sci. Health A, 42, 1869-1878.

JEMAI (Japan Environmental Management Association for Industry) (2008) JIS K0102 Testing methods for industrial wastewater, Japanese Standard Association, Japan.

Kartinen E. O. and Martin C. J. (1995) An overview of arsenic removal processes, Desalination, 103, 79-88.

Katsoyiannis I. A. and Zouboulis A. I. (2002) Removal of arsenic from contaminated water sources by sorption on to iron-oxide-coated polymeric materials, Water Res., 36, 5141-5155.

Katsoyiannis I. A., Zouboulis A. I. Althoff H. and Bartel H. (2002) As(III) removal from groundwater using fixed-bed upflow bioreactors, Chemosphere, 47, 325-332.

Katsoyiannis I. A. and Zouboulis A. I. (2004) Application of biological process for the removal of arsenic from groundwaters, Water Res., 38, 17-26.

Khan A. H., Rasul S. B., Munir A. K. M., Habibuddowla M., Alauddin M., Newaz S. S. and Hussam A. (2000) Appraisal of a simple arsenic removal method for groundwater of Bangladesh, J. Environ. Sci. Health A, 35, 1021-1041. 
Leupin O. X. and Hug S. J. (2005) Oxidation and removal of arsenic (III) from aerated groundwater by filtration through sand and zero-valent iron, Water Res., 39, 17291740.

Lien H. L. and Wilkin R. T. (2005) High-level arsenite removal from groundwater by zero-valent iron, Chemosphere, 59, 377-386.

Manning B. A., Fendorf S. E. and Goldberg S. (1998) Surface structures and stability of arsenic(III) on Goethite: Spectroscopic evidence for inner-sphere complexes, Environ. Sci.Technol., 32, 2383-2388.

Manning M. L. and Amrhein H. C. (2002) Arsenic (III) and arsenic (V) reaction with zerovalent iron corrosion products, Environ. Sci. Technol., 36, 5455-5461.

Mazumdar D. N. G., Haque R., Ghosh N., De B. K., Santra A., Chakraborti D. and Smith A. H. (1998) Arsenic levels in drinking water and the prevalence of skin lesions in West Bengal India, Int. J. Epidemiol., 27, 871-887.

Meng X. G., Korfiats G. P., Jing C. Y. and Christodoulatos C. (2001) Redox transformation of arsenic and iron in water treatment sludge during aging and TCLP extraction, Environ. Sci. Technol., 35, 3476-3481.

Michalakos G. D., Nieva J. M., Vayenas D. V. and Lyberatos G. (1997) Removal of iron from potable water using a trickling filter, Water Res., 31, 991-996.

Mounchet P. (1992) From conventional to biological removal of iron and manganese in France, J. Am. Water Works Assoc., 84, 158-166.

Oyanedel-Craver V. A. and Smith J. A. (2008) Sustainable colloidal-silver-impregnated ceramic filter for point-of-use water treatment, Environ. Sci. Technol., 42, 927-933.

Pontius F. W., Brown G. K. and Chien J. C. (1994) Health implications of arsenic in drinking water, J. Am. Water Works Assoc., 86, 52-63.

Roberts L. C., Hug S. J., Ruettimann T., Billah M. M., Khan A. W. and Rahman M. T. (2004) Arsenic removal with iron (II) and iron (III) in waters with high silicate and phosphate concentrations, Environ. Sci. Technol., 38, 307-315.

Shafiquzzaman M., Mishima I. and Nakajima J. (2008) Arsenic removal from ground water by sand filtration during biological iron oxidation, Jpn. J. Water Treat. Biol., 44, 11-20.

Shafiquzzaman M., Azam M. S., Mishima I. and Nakajima J. (2009) Technical and social evaluation of arsenic mitigation in rural Bangladesh, J. Health Popul. Nutr., 27, 674-683.

Shafiquzzaman M., Azam M. S., Nakajima J. and Bari Q. H. (2010) Arsenic leaching characteristics of the sludges from iron based removal process, Desalination, 261, 41-45.

Shafiquzzaman M., Azam M. S., Nakajima J. and Bari Q. H. (2011) Investigation of arsenic removal performance by a simple iron removal ceramic filter in rural households of Bangladesh, Desalination, 265, 60-66.

Smith A. H., Goycolea M., Haque R. and Biggs M. L. (1998) Marked increase in bladder and lung cancer mortality in a region of northern Chile due to arsenic in drinking water, Am. J. Epidemiol., 147, 660- 669.

Snoeyink V. L. and Jenkins D. (1980) Water chemistry. John Wiley, New York, USA.

Su C. and Puls R. W. (2001a) Arsenate and arsenite removal by zerovalent iron: Kinetics, redox transformation, and implication for in situ groundwater remediation, Environ. Sci. Technol., 35, 1487-1492. 
Su C. and Puls R. W. (2001b) Arsenate and arsenite removal by zerovalent iron: Effects of phosphate, silicate, carbonate, borate, sulphate, chromate, molybdate, and nitrate, relative to chloride, Environ. Sci. Technol., 35, 4562-4568.

Su C. and Puls R. W. (2003) In situ remediation of arsenic in simulated groundwater using zerovalent iron: Laboratory column tests on combined effects of phosphate and silicate, Environ. Sci. Technol., 37, 2582-2587.

USEPA (1986) Hazardous waste management system; land disposal restriction. Appendix I to part 268: Toxicity characteristics leaching procedure (TCLP). Federal Register; 51(216) p.40643-40654.

USEPA (2002) Office of ground water and drinking water implementation guidance for the arsenic rule, EPA Report -816-D-02-005 (I3-I4), USEPA,Cincinnati, USA.

WHO (1996) Guidelines for drinking-water quality, Health criteria and other supporting information, World Health Organization, $2^{\text {nd }}$ ed., Vol. 2, pp.940-49.

Yang L., Ning X., Chen K. and Zhou H. (2007) Preparation and properties of hydroxyapatite filters for microbial filtration, Ceramics Int., 33, 483-489. 